\title{
THE
}

\section{Bloom-forming macroalgae (Ulva spp.) inhibit the growth of co- occurring macroalgae and decrease eastern oyster larval survival}

\author{
Lindsay A. Green-Gavrielidis \\ University of Rhode Island, lindsaygreen@uri.edu \\ Fiona MacKechnie \\ University of Rhode Island \\ Carol S. Thornber \\ University of Rhode Island, thornber@uri.edu \\ Marta Gomez-Chiarri \\ University of Rhode Island, gomezchi@uri.edu
}

Follow this and additional works at: https://digitalcommons.uri.edu/nrs_facpubs

\section{The University of Rhode Island Faculty have made this article openly available.}

Please let us know how Open Access to this research benefits you.

This is a pre-publication author manuscript of the final, published article.

Terms of Use

This article is made available under the terms and conditions applicable towards Open Access

Policy Articles, as set forth in our Terms of Use.

\section{Citation/Publisher Attribution}

Green-Gavrielidis LA, MacKechnie F, Thornber CS, Gomez-Chiarri M (2018) Bloom-forming macroalgae (Ulva spp.) inhibit the growth of co-occurring macroalgae and decrease eastern oyster larval survival. Mar Ecol Prog Ser 595:27-37. https://doi.org/10.3354/meps12556

Available at: https://doi.org/10.3354/meps12556

This Article is brought to you for free and open access by the Natural Resources Science at DigitalCommons@URI. It has been accepted for inclusion in Natural Resources Science Faculty Publications by an authorized administrator of DigitalCommons@URI. For more information, please contact digitalcommons-group@uri.edu. 
1 Bloom-forming macroalgae (Ulva spp.) inhibit the growth of co-occurring macroalgae and decrease eastern oyster larval survival

5 Lindsay A. Green-Gavrielidis ${ }^{1 *}$, Fiona MacKechnie ${ }^{1,2}$, Carol S. Thornber ${ }^{1}$, and Marta Gomez-Chiarri $^{3}$

${ }^{1}$ Department of Natural Resources Science, University of Rhode Island, Kingston, RI 02881, U.S.A.

112 Present address: Scottish Association for Marine Science, Scottish Marine Institute, Oban, Argyll, PA37 1QA, United Kingdom

$14{ }^{3}$ Department of Fisheries, Animal, and Veterinary Sciences, University of Rhode Island, Kingston, RI, 02881

*Corresponding author lindsaygreen@uri.edu and decrease eastern oyster larval survival. Mar Ecol Prog Ser 595:27-37. 


\section{Abstract}

2 Macroalgal blooms have increased in frequency worldwide due to anthropogenic

3 activities. Algal blooms can disrupt recreational activities, interfere with fisheries, and

4 deplete oxygen during decomposition. Narragansett Bay has experienced macroalgal

5 blooms dominated by blade-forming Ulva for over a century. Evidence from other

6 systems has suggested that Ulva can negatively impact other organisms. The first

7 objective of this study was to determine whether bloom-forming Ulva compressa and $U$.

8 rigida inhibit the growth of co-occurring macroalgae, Gracilaria vermiculophylla,

9 Cystoclonium purpureum, and Chondrus crispus, during co-culture via laboratory-based

10 assays. We found that $U$. compressa and $U$. rigida significantly inhibited the growth of

11 all three macroalgae. We were able to verify the negative effects of Ulva compressa, but

12 not $U$. rigida on the growth of G. vermiculophylla in flow-through seawater tanks. Our

13 second objective was to determine if Ulva exudate decreased the survival of eastern

14 oyster larvae in laboratory challenge experiments. We documented a significant negative

15 effect of Ulva exudate on oyster survival, which depended on both the Ulva species and

16 the nutrient condition. The strongest effect on oyster larval survival was seen in larvae

17 exposed to nutrient replete Ulva compressa exudate, which had less than $30 \%$ relative

18 survival after one week. Our results indicate that bloom-forming Ulva has the potential to

19 inhibit co-occurring macroalgae and cause oyster larval mortality.

20 KEY WORDS- Ulva compressa, Ulva rigida, macroalgal blooms, larval mortality.

\section{Introduction}

22 Macroalgal blooms, generally consisting of green ulvoid macroalgae (commonly

23 referred to as "green tides"), have been increasing worldwide (Valiela et al. 1997, Nelson 
1 et al. 2003, Teichberg et al. 2010, Liu et al. 2013, Smetacek \& Zingone 2013) and are

2 common occurrences on the northeastern coast of the United States (Bricker et al. 2008).

3 Macroalgal blooms are typically driven by anthropogenic nutrient loading in shallow

4 estuaries and can result in declines in seagrass (Valiela et al. 1997, McGlathery 2001),

5 perennial algae, and overall community diversity (Worm \& Lotze 2006). During bloom

6 decomposition, macroinvertebrate abundance declines (Cummins et al. 2004) and

7 dissolved organic nitrogen is released into the water column (Tyler et al. 2001) that can

8 fuel further primary production (reviewed by Raffaelli et al. 1998). Macroalgal blooms

9 are also costly to clean up (Atkins et al. 1993, Lapointe \& Bedford 2007).

10 Narragansett Bay, Rhode Island, U.S.A is a $380 \mathrm{~km}^{2}$ semi-diurnal, well mixed

11 tidal estuary (Deacutis et al. 2006). The northern part of the bay is heavily populated and

12 there are three major urban freshwater inflows that contribute anthropogenic nutrients to

13 the system (Deacutis et al. 2006, Thornber et al. 2008). Greenwich Bay, a small sub-

14 embayment on the western side of Narragansett Bay, has been plagued by persistent

15 macroalgal blooms during the summer months for more than a century, dominated by

16 Ulva compressa Linnaeus and U. rigida C. Agardh (Granger et al. 2000, Guidone et al.

17 2013, Thornber et al. 2017). For example, Granger et al. (2000) documented 100-400 g

18 dry mass $/ \mathrm{m}^{2}\left(1015-4060 \mathrm{~g}\right.$ wet mass $/ \mathrm{m}^{2}$ based on the conversion factors of Angell et al.

19 2012) of Ulva in Greenwich Bay in 1996, while Guidone \& Thornber (2013) observed a

20 maximum biomass of $>1800 \mathrm{~g}$ wet mass $/ \mathrm{m}^{2}$ in 2010 .

21 Although green macroalgal blooms can have significant deleterious impacts on

22 coastal ecosystems (see Fletcher 1996), they have historically been considered non-toxic

23 (Valiela \& Cole 2002, Anderson 2009). Green macroalgae have been considered to be 
1 less likely than red and brown macroalgae to inhibit or harm co-occurring organisms

2 (Harlin 1987, Valiela et al. 1997), and therefore, competition between green macroalgae

3 and co-occurring species has been investigated less than with red and brown macroalgae

4 (Hurd et al. 2014). However, growing evidence has suggested that ulvoid species of green

5 macroalgae (species in the Family Ulvophyceae) can inhibit the growth, germination,

6 and/or development of co-occurring organisms (Nelson et al. 2003, Nan et al. 2008,

7 Nelson \& Gregg 2013, Van Alstyne et al. 2014, Van Alstyne et al. 2015; Table 1).

8 Evidence of ulvoid species suppressing the growth of phytoplankton, especially species

9 that cause harmful algal blooms, has been especially strong (e.g. Jin \& Dong 2003, Nan

10 et al. 2008, Wang et al. 2012, Accoroni et al. 2015).

11 While several researchers have reported positive and negative effects of ulvoid

12 species on invertebrates (Nelson \& Gregg 2013, Van Alstyne et al. 2014), to date there

13 have been no reports of the potential effects of Ulva spp. on the economically important

14 eastern oyster, Crassostrea virginica. Muñoz et al. (2012) showed that the presence of

15 young Ulva thalli improved the post-larval growth rate of the commercially produced red

16 abalone Haliotis rufescens, while Huggett et al. (2005) reported high settlement of the

17 abalone H. rubra on two ulvoid species. Lamb (2015) noted that the presence of Ulva

18 thalli in aquaculture bags resulted in slower growth of adult Pacific oysters, Crassostrea

19 gigas. Currently there are 315 aquaculture farms that cultivate the eastern oyster $C$.

20 virginica in the U.S. (USDA 2014), many of them in areas where Ulva is present.

21 Therefore, it is important to understand the interactions between bloom-forming Ulva and

22 the eastern oyster. 
Given the mounting evidence from other systems dominated by ulvoid

2 macroalgae, we hypothesized that blade-forming species of Ulva, namely the bloom-

3 forming $U$. compressa and $U$. rigida, inhibit the growth of co-occurring organisms in

4 Narragansett Bay. The first objective of this study was to determine if $U$. compressa or $U$.

5 rigida negatively affect the growth of co-occurring macroalgae. Our second objective

6 was to determine if exudate from U. compressa or $U$. rigida affected the survival of

7 eastern oyster larvae. Testing the impacts of Ulva exudate on oyster larvae was important

8 for two reasons. First, Ulva blooms form in coastal ponds where eastern oyster

9 populations co-occur and oyster cultivation is present (Thorne-Miller et al. 1983, Beutel

10 2017). Second, larvae should be included in assays because they are generally more

11 sensitive to heavy metals and pollutants than adults (Connor 1972, His et al. 1999). We

12 discuss our findings in light of increased coastal development and eutrophication, which

13 will likely fuel increasing macroalgal blooms in the future.

$15 \quad$ Materials and Methods

\section{Genetic identification of Ulva}

17 The genus Ulva contains many blade-forming species that appear

18 morphologically similar, however, the cell shape and numbers of pyrenoids can be used

19 to distinguish between $U$. compressa and $U$. rigida (Guidone et al. 2013). We examined

20 each blade of Ulva and determined its identity based on the morphological characteristics

21 detailed by Guidone et al. (2013). Ulva compressa cells are polygonal with rounded

22 corners and contain a single pyrenoid, while $U$. rigida cells are polygonal with angular

23 corners and contain 2-4 pyrenoids. However, Ulva morphology can be highly variable 
1 (Hofmann et al. 2010), so we also used DNA barcoding to verify the accuracy of our

2 morphological identifications. We amplified a $678 \mathrm{bp}$ segment from the $r b c \mathrm{~L}$ gene of

3 specimens used in these experiments following the methods of Guidone et al. (2013)

4 except that we used a modified CTAB plant DNA extraction protocol based on Doyle and

5 Doyle (1987). The raw sequence chromatograms were trimmed and proofread in 4Peaks

6 (v.1.8, Nucleobytes) and sequences were aligned and assembled in Seq Man Pro (v.12,

7 DNA Star Inc.).

\section{Genetic identification of Gracilaria}

10 Two species of Gracilaria occur in Narragansett Bay, the native Gracilaria

11 tikvahiae McLachlan and the introduced Gracilaria vermiculophylla (Ohmi) Papenfuss

12 (Nettleton et al. 2013). These two species have morphological characteristics that

13 overlap, and therefore restricted fragment length polymorphism (RFLP) and selected

14 DNA barcoding was performed to determine the species identification of material from

15 the laboratory-based mesocosm trials.

16 DNA was extracted using the modified CTAB plant DNA extraction protocol

17 based on Doyle and Doyle (1987). Polymerase chain reaction was performed in $50 \mu \mathrm{L}$

18 volumes containing $10 \mu \mathrm{L}$ of $5 \mathrm{X}$ GoTaq ${ }^{\circledR}$ Flexi DNA Polymerase (Promega

19 Corporation), $7 \mu \mathrm{L}$ of $25 \mathrm{mM} \mathrm{Mg}{ }^{2+}, 1 \mu \mathrm{L}$ of $2.5 \mathrm{mM}$ dNTP, and $4 \mu \mathrm{L}$ of extracted DNA

20 template (10-50 ng). A $307 \mathrm{bp}$ segment from the mitochondrial gene COX1 was used for

21 species identification and was amplified with the forward primer CO1F328 and the

22 reverse primer CO1R634 (Nettleton et al. 2013). The PCR profile consisted of an initial

23 denaturation at $95^{\circ} \mathrm{C}$ for 2 minutes, followed by 30 cycles of $57^{\circ} \mathrm{C}$ for 1 minute, $73^{\circ} \mathrm{C}$ for 
11 minute, and $95^{\circ} \mathrm{C}$ for 1 minute followed by a final minute at $57^{\circ} \mathrm{C}$ and a final extension

2 at $73^{\circ} \mathrm{C}$ for 6 minutes. RFLP analysis was performed on the PCR samples after

3 amplification following the protocol of Nettleton (2012). In addition to the RFLP

4 analysis, three samples were chosen at random to be sequenced. PCR purification, sample

5 preparation, sequencing, and sequence analysis were performed as described above (see

6 "Genetic Identification of Ulva").

\section{Effects of Ulva on co-occurring macroalgae}

9 In order to determine whether Ulva compressa or $U$. rigida suppress the growth of

10 other macroalgae, we performed a series of co-culture experiments. We co-cultured

11 isolated tips of three species that are common in Ulva blooms in Narragansett Bay

12 (Thornber, unpub. data), Gracilaria vermiculophylla, Cystoclonium purpureum (Hudson)

13 Batters, and Chondrus crispus Stackhouse from adult thalli, in separate trials, with the

14 bloom-forming $U$. compressa and $U$. rigida. We then conducted a series of semi-

15 controlled trials with U. compressa, U. rigida, and G. vermiculophylla in outdoor flow-

16 through seawater tanks.

17 All macroalgal material was collected in Narragansett Bay, Rhode Island during

18 low tide in the intertidal or shallow subtidal zone and transported to the laboratory on ice

19 for processing. Upon arrival at the laboratory, all material was cleaned with sterile

20 seawater to remove epiphytes. Following epiphyte removal, tips of G. vermiculophylla,

21 C. purpureum, and C. crispus were excised using sterile razor blades, rinsed three times

22 with sterile seawater (30-32 psu), and placed in $250 \mathrm{~mL}$ flasks with sterile Von Stosch

23 Enriched (VSE) natural seawater (Ott 1966) under acclimation conditions $\left(20-23^{\circ} \mathrm{C}, 100\right.$ 
$1 \mu \mathrm{mol}$ photons $\mathrm{m}^{-2} \mathrm{~s}^{-1}$, and a 16:8 Light: Dark photoperiod with constant aeration); total

2 acclimation to laboratory conditions occurred for at least 3 days, with at least 24 hours

3 allowed for wound healing following tip cutting. Natural seawater was obtained from the

4 Marine Science Research Center (MSRC) at the University of Rhode Island's

5 Narragansett Bay Campus, filtered to $0.2 \mu \mathrm{M}$, and autoclaved prior to use.

6 After the acclimation period, the blotted-dry wet mass of tips of $G$.

$7 \quad$ vermiculophylla were taken and the tips were placed in individual $1 \mathrm{~L}$ mesocosms that

8 were divided in half with mesh with $1 \mathrm{~mm}^{2}$ openings and filled with $400 \mathrm{~mL}$ of sterile

9 VSE seawater. On the other side of the mesh, $0.4 \mathrm{~g}$ of either $U$. compressa or $U$. rigida

$10(=1 \mathrm{~g} / \mathrm{L})$ was added. Experimental culture conditions were equivalent to those provided

11 during the acclimation period and light was supplied from the top to ensure no

12 interspecific shading. In total, there were 21 mesocosms with seven replicates each of the

$13 U$. compressa treatment, U. rigida treatment, and mesocosm control (G. vermiculophylla

14 in mesh-divided mesocosm without Ulva) per trial. In order to prevent nutrient limitation,

$15 \mathrm{NO}_{3}{ }^{-}$was measured daily as a proxy for nutrient concentrations, and all VSE nutrients

$16\left(\mathrm{NaNO}_{3}, \mathrm{Na}_{2} \mathrm{HPO}_{4} \cdot 12 \mathrm{H}_{2} \mathrm{O}, \mathrm{FeSO}_{4} \cdot 7 \mathrm{H}_{2} \mathrm{O}, \mathrm{MnCl}_{2} \cdot 4 \mathrm{H}_{2} \mathrm{O}, \mathrm{Na}_{2} \mathrm{EDTA} \cdot 2 \mathrm{H}_{2} \mathrm{O}\right.$, Thiamine-

$17 \mathrm{HCl}$, Biotin, Vitamin $\mathrm{B}_{12}$ ) were replenished based on nitrate depletion. Nitrate was

18 measured using an API Nitrate Test Kit modified for a $1 \mathrm{~mL}$ sample. Nitrate was

19 considered depleted if it was below $40 \mathrm{ppm}$ (i.e. full VSE enrichment) and was

20 replenished to this level daily. On average, we replenished nutrients in the $U$. compressa

21 treatment every other day and the $U$. rigida treatment every 2.6 days.

22 On Days 2, 4, 6 and 8 of each trial, the blotted-dry wet mass of $G$.

23 vermiculophylla tips was measured. Relative growth rate (RGR) was calculated using the 
1 following equation: RGR $(\%)=100 \times\left[\ln \left(\mathrm{L}_{2} / \mathrm{L}_{1}\right) /\left(\mathrm{t}_{2}-\mathrm{t}_{1}\right)\right]$, where $\mathrm{L}_{2}$ and $\mathrm{L}_{1}$ were the blade

2 weight at times $\mathrm{t}_{2}$ and $\mathrm{t}_{1}$, respectively. A total of two G. vermiculophylla trials were

3 performed. The same experimental design was used to conduct separate trials with

$4 \quad$ Cystoclonium purpureum (2 trials) and Chondrus crispus (2 trials). Daily pH levels were

5 determined for the first Chondrus crispus trial only using an EcoTestr ${ }^{\mathrm{TM}} \mathrm{pH}$ meter

6 (Oakton $®)$.

8 Gracilaria vermiculophylla control trials

9 To confirm that the observed results were due to the presence of Ulva and not

10 simply due to the presence of another macroalga, two G. vermiculophylla control trials

11 with the same experimental design as the co-culture trials described above were

12 performed. Seven replicates each of two treatments, G. vermiculophylla and mesocosm

13 control, were included in each trial. The G. vermiculophylla treatment had $0.4 \mathrm{~g}(=1 \mathrm{~g} / \mathrm{L})$

14 of G. vermiculophylla on one side of the mesh and a tip of G. vermiculophylla on the

15 other side.

\section{Semi-controlled outdoor flow-through seawater tank trials}

18 In order to determine whether Ulva suppressed the growth of co-occurring

19 macroalgae, semi-controlled trials in outdoor flow-through seawater tanks were

20 conducted at the MSRC during July $2015(\mathrm{n}=4)$. G. vermiculophylla $(0.85 \pm 0.04 \mathrm{~g})$ was

21 co-cultured with $1.5 \mathrm{~g}$ of either U. compressa, U. rigida, or G. vermiculophylla (control)

22 in separate flow-through tanks $(\mathrm{n}=3)$. Ulva compressa, U. rigida, or G. vermiculophylla

$23(1 \mathrm{~g} / \mathrm{L})$ were placed in individual mesocosms $(16 \times 11.9 \times 7.62 \mathrm{~cm})$ covered with mesh on 
1 all sides (mesh size $=1.6 \mathrm{~cm}^{2}$ ) that was connected with cable ties to a mesocosm

2 containing G. vermiculophylla. The mesocosm pairs were arranged so that Ulva was

3 upstream of G. vermiculophylla. The mass of G. vermiculophylla was measured on Day 0

4 and Day 7 and relative growth rate (RGR) was calculated. Due to space limitations, four

5 individual trials were conducted with a single replicate from each treatment in each trial.

6 Water temperature was measured using HOBO Tidbit v2 water temperature loggers

7 (Onset Computer Corporation) and averaged $23.6^{\circ} \mathrm{C}$ (individual tanks ranged from

$8 \quad 23.16^{\circ} \mathrm{C} \pm 0.09$ to $27.28^{\circ} \mathrm{C} \pm 0.51$; mean $\left.\pm \mathrm{SE}\right)$.

\section{Effects of Ulva on oyster larvae}

11 In order to determine whether exudate from U. compressa or U. rigida affected

12 the survival of eastern oyster larvae, a series of challenge experiments were conducted.

13 Ulva compressa and $U$. rigida $(5 \mathrm{~g} / \mathrm{L})$ were cultured in nutrient replete (i.e. supplied full

14 VSE nutrients) or nutrient deplete (i.e. no nutrients supplied) seawater for 2-3 days, under

15 the same conditions outlined above, to produce Ulva exudate. This concentration of Ulva

16 was chosen to reflect those present in Ulva blooms. Bloom biomass can exceed 8,000

$17 \mathrm{~g} / \mathrm{m}^{3}$ in the subtidal and $3,000 \mathrm{~g} / \mathrm{m}^{2}$ in the intertidal (Thornber et al. 2017). In the nutrient

18 replete cultures, $\mathrm{NO}_{3}{ }^{-}$was measured daily as a proxy for nutrient concentrations, and all

19 VSE nutrients were replenished based on nitrate depletion. However, exudate was not

20 collected for use in the challenge experiments until all $\mathrm{NO}_{3}{ }^{-}$was depleted in the nutrient

21 replete cultures, since nitrate can be toxic to juvenile and adult shellfish (Epifanio \& Srna

22 1975).

23 At the end of the culture period, Ulva material was removed from the seawater 
1 and the $\mathrm{pH}$ of exudate was adjusted to 7.9-8.0. The exudate was then filter sterilized (0.2

$2 \mu \mathrm{M})$. Oyster larvae were obtained from the Blount Shellfish Hatchery at Roger Williams

3 University and acclimated to laboratory conditions in sterile natural seawater on a shaker

4 plate $(40 \mathrm{rpm})$. Larvae were fed $2 \mathrm{~mL} / \mathrm{L}$ of Shellfish Diet $1800^{\circledR}$ (Reed Mariculture,

5 Campbell, CA) every other day while in the laboratory. At the start of the experiments

6 oyster larvae were between 3 and 9 days old.

$7 \quad$ Challenge experiments (3 trials) were conducted in 6-well culture plates following

8 a slight modification of previously developed protocols (Karim et al. 2013, Sohn et al.

9 2016). Oyster larvae ( 50-100) were collected onto $45 \mu \mathrm{M}$ nylon mesh, washed with

10 filtered sterile seawater and placed into each well with $5 \mathrm{~mL}$ of the assigned treatment

11 water. Treatments included $U$. compressa + nutrients, $U$. compressa - nutrients, $U$. rigida

12 + nutrients, and $U$. rigida - nutrients. Each well plate contained three wells of a treatment

13 and three wells of control (sterile seawater). Larval survival was assessed on Days 3, 5,

14 and 7 by counting dead larvae (i.e. empty shells) in each well using an inverted

15 microscope. At the end of the experiment, larvae were fixed by adding $70 \%$ ethanol to

16 each well to obtain a total count. Percent survival of oyster larvae was calculated for each

17 day using the following equation: $\%$ survival $=($ total - dead $) \div$ total $\times 100$. In instances

18 where $\%$ survival was less than 0 , due to human error in counting, survival was adjusted

19 to $0 \%$ (8 out of 141 observations). The relative percent survival (of control) was

20 calculated by randomly pairing each treatment well with a control well from the same

21 plate using the following equation: relative percent survival $=(\%$ survival of treatment $\div$

$22 \%$ survival of control) $\times 100$. 


\section{Statistical Analysis}

2 We used separate split-plot analysis of variance (ANOVA) tests to determine the

3 effect of co-culture with $U$. compressa and $U$. rigida on the growth rate of $G$.

4 vermiculophylla, C. purpureum, and C. crispus with treatment as the main plot (3 levels)

5 and time as the sub-plot (4 levels); Trial $(\mathrm{n}=2)$ was included as a blocking factor. We also

6 used a split-plot ANOVA to test the effect of co-culture with G. vermiculophylla on the

7 growth of G. vermiculophylla tips (G. vermiculophylla control trial). We used a one-way

8 ANOVA to test the effect of treatment (3 levels) on the growth rate of G. vermiculophylla

9 in semi-controlled outdoor flow-through seawater tank trials, with Trial $(n=4)$ included as

10 a blocking factor. We used a two-way split-split-plot ANOVA to determine the effect of

11 Ulva species (main plot, 2 levels), nutrients (sub-plot, 2 levels), and day (sub-sub plot, 3

12 levels) on the percent survival (of control) of oyster larvae from the challenge

13 experiment. Trial $(\mathrm{n}=3)$ was used as a blocking factor.

14 Prior to analyses, all data were examined for normality and homogeneity of

15 variances and transformed where appropriate; G. vermiculophylla growth rate was log

16 transformed to ensure homogeneity of variances. Our growth and percent survival data

17 did not meet the assumption of normality, even after transformation; however ANOVA is

18 robust to deviations from normality when experiments have balanced designs and

19 reasonable sample sizes (Underwood 1997). Post-hoc comparisons were made using

20 Tukey's Honestly Significant Differences tests. All statistical analyses were conducted

21 using JMP (v.12.0.1, SAS Institute Inc.).

22

\section{Results}




\section{Genetic identification of Ulva}

All U. compressa specimens identified using morphological characteristics $(n=14)$

3 in this study were verified by DNA barcoding using MegaAlign (v.12, DNA Star Inc.) to

4 match U. compressa from the Northwest Atlantic (GenBank ${ }^{\circledR}$ Accession: KC582355.1).

5 Although the holotype sequence for U. compressa is not currently available, our

6 sequences agreed with the $U$. compressa concept identified by Guidone et al. (2013).

7 The topotype of $U$. rigida is labeled on GenBank ${ }^{\circledR}$ as $U$. armorica (Shimada et al.

8 2003; Guidone et al. 2013), which has since been synonymized with $U$. rigida. All $U$.

9 rigida specimens identified using morphological characteristics in this study $(\mathrm{n}=14)$ were

10 verified to match $U$. rigida from the Northwest Atlantic (GenBank ${ }^{\circledR}$ Accession:

11 EU484395.1) and were 99\% identical to the $U$. rigida topotype (GenBank ${ }^{\circledR}$ Accession:

12 AB097630).

\section{Genetic identification of Gracilaria}

15 All Gracilaria specimens used in the laboratory co-culture experiments ( $\mathrm{n}=6$ for

16 Ulva experiments and $\mathrm{n}=8$ for G. vermiculophylla control) were identified through RFLP

17 analysis as G. vermiculophylla. The three samples that were sequenced were identical to

18 G. vermiculophylla from the Northwest Atlantic (GenBank ${ }^{\circledR}$ Accession: JQ675712.1)

19 based on Nettleton et al. (2013).

\section{Effects of Ulva on co-occurring macroalgae}

22 The effect of treatment (Ulva compressa, $U$. rigida, and mesocosm control) on the

23 relative growth rate of Gracilaria vermiculophylla was dependent on Day (Treatment x 
1 Day: $\mathrm{F}_{6,153}=2.2, \mathrm{p}=0.048$; Figure 1a; Table S1). After eight days of co-culture, the RGR

2 of G. vermiculophylla without Ulva $\left(7.44 \pm 1.35 \% \mathrm{~d}^{-1}\right)$ was more than three times higher

3 than G. vermiculophylla co-cultured with $U$. rigida $\left(2.31 \pm 0.69 \% \mathrm{~d}^{-1}\right) . G$.

4 vermiculophylla co-cultured with $U$. compressa had virtually no change in mass on Day 8

5 and grew significantly slower than G. vermiculophylla tips in the mesocosm control

$6 \quad(\mathrm{p}=0.004 ;$ Figure 1a).

7 Day significantly affected the relative growth rate of Cystoclonium purpureum

$8 \quad\left(\mathrm{~F}_{3,151}=8.2, \mathrm{p}<0.001\right)$ and was dependent on Treatment (Treatment $x$ Day: $\mathrm{F}_{6,151}=3.9, \mathrm{p}$

$9=0.001$; Figure 1b; Table S2). There was no significant difference between the RGR of

10 C. purpureum tips co-cultured with $U$. rigida $\left(0.94 \pm 1.28 \% \mathrm{~d}^{-1}\right)$ and the mesocosm

11 control $\left(6.37 \pm 0.96 \% \mathrm{~d}^{-1}\right)$, after 8 days of co-culture. However, after 8 days of co-culture

12 tips co-cultured with $U$. compressa grew significantly slower $\left(-5.39 \pm 1.22 \% \mathrm{~d}^{-1}\right)$ than

13 tips co-cultured with $U$. rigida $(\mathrm{p}=0.024)$ or alone $(\mathrm{p}<0.001$; Figure $1 \mathrm{~b}$; Table 2$)$.

14 The relative growth rate of Chondrus crispus was significantly affected by

15 Treatment ( $U$. compressa, $U$. rigida, and mesocosm control; $\left.\mathrm{F}_{2,152}=39.3, \mathrm{p}=0.025\right)$ with

16 the effect of Treatment dependent on Day (Day: $F_{3,151}=8.7$, $p<0.001$; Treatment $x$ Day:

$17 \mathrm{~F}_{6,151}=2.6, \mathrm{p}=0.018$; Figure 1c; Table S3). C. crispus thalli grown without Ulva grew

18 significantly faster than thalli grown with $U$. rigida $(\mathrm{p}=0.025)$ or $U$. compressa $(\mathrm{p}=0.019)$

19 after six days of co-culture (Figure 1c; Table 3). On Day 8, C. crispus thalli in both Ulva

20 treatments were losing mass while C. crispus cultured without Ulva was growing at a

21 RGR of $5.7 \pm 0.5 \% \mathrm{~d}^{-1}$ (Figure 1c, Table 3 ). In the first $C$. crispus trial, the $\mathrm{pH}$ levels

22 were $8.1 \pm 0.03,9.2 \pm 0.2$, and $8.9 \pm 0.2$ in the mesocosm control, $U$. compressa treatment,

23 and $U$. rigida treatment, respectively. 
There was no effect of co-culture with $G$. vermiculophylla on the relative growth

2 rate of tips of $G$. vermiculophylla in the control trials (Treatment: $F_{1,101}=3.2, p=0.157$;

3 data not shown). The average RGR of G. vermiculophylla cultured alone was $6.29 \pm 0.52$

$4 \% \mathrm{~d}^{-1}$, while tips co-cultured with G. vermiculophylla had an average RGR of $3.79 \pm 0.90$

$5 \% \mathrm{~d}^{-1}$.

6 The overall relative growth rate of G. vermiculophylla in outdoor flow-through

7 seawater tank trials was significantly different among treatments $\left(F_{2,6}=5.8, p=0.0393\right)$.

8 There was no significant difference in the RGR of G. vermiculophylla between the

9 mesocosm control $\left(8.5 \pm 1.7 \% \mathrm{~d}^{-1}\right)$ and $U$. rigida $\left(7.7 \pm 3.0 \% \mathrm{~d}^{-1}\right)$ treatments or between

$10 U$.rigida and $U$. compressa $\left(3.9 \pm 0.9 \% \mathrm{~d}^{-1}\right)$ treatments. However, G. vermiculophylla in

11 the mesocosm control grew significantly faster than G. vermiculophylla co-cultured with

$12 U$. compressa $(\mathrm{p}=0.043)$.

\section{Effects of Ulva on oyster larvae}

15 Survival in the control oyster larvae wells was good throughout the 7-day

16 challenge experiment. Mean survival in the controls was $97.8 \% \pm 1.3 \%$ on Day $3,89.4 \%$

$17 \pm 2.5 \%$ on Day 5 and $71.9 \% \pm 3.8 \%$ on Day 7 (mean \pm SE, $n=48$ ).

18 Relative percent survival of oyster larvae was significantly lower when larvae

19 were cultured in exudate from $U$. compressa $(79.5 \pm 1.9 \%)$ than from $U$. rigida $(98.1 \pm$

$201.9 \% ; \mathrm{F}_{1,2}=47.4, \mathrm{p}=0.008$; Figure 2; Table S4). The effect of Ulva species on oyster

21 larval survival was dependent on nutrients and time (Ulva species $\times$ nutrients $\times$ day $=$

$22 \mathrm{~F}_{2,122}=6.7, \mathrm{p}=0.002$; Table $\left.\mathrm{S} 4\right)$. Post hoc analysis revealed no difference between the

23 treatments after 3 days of culture. However, oyster survivorship was significantly lower 
1 when cultured in $U$. compressa + nutrients than $U$. compressa - nutrients $(\mathrm{p}<0.001)$ and

$2 U$. rigida + nutrients $(\mathrm{p}<0.001)$ after 5 days of culture (Figure 2$)$. This pattern was

3 consistent after 7 days, when oyster survival in the $U$. compressa + nutrients treatment

4 was less than $30 \%$ (Figure 2).

6 Discussion

7 While green macroalgae have been traditionally thought of as non-toxic,

8 increasing evidence has shown that species of ulvoid macroalgae can inhibit co-occurring

9 phytoplankton (Nan et al. 2008; Tang \& Gobler 2011), macroalgae (Gao et al. 2014), and

10 invertebrates (Nelson \& Gregg 2013, Van Alstyne et al. 2014, Peckol \& Putnam 2017).

11 Here, we found that two dominant bloom-forming ulvoid species, Ulva compressa and $U$.

12 rigida, inhibit the growth of the co-occurring red macroalgae, Gracilaria

13 vermiculophylla, Cystoclonium purpureum, and Chondrus crispus at Ulva concentrations

14 that are observed during blooms (Thornber et al. 2017). Thornber et al. (2017)

15 documented blooms dominated by Ulva that reached a biomass of $>3000 \mathrm{~g} / \mathrm{m}^{2}$ in the

16 intertidal and $>8000 \mathrm{~g} / \mathrm{m}^{3}$ in the subtidal zone; blooms with over $12,000 \mathrm{~g} / \mathrm{m}^{3}$ were

17 recently documented in a coastal salt pond (Green-Gavrielidis et al. 2017). We were able

18 to validate the negative effect of $U$. compressa on the growth rate of G. vermiculophylla

19 through trials in outdoor flow-through seawater tanks.

20 Previous studies have reported that species of Ulva (e.g. Ulva linza; Gao et al.

21 2014) inhibited the growth and photosynthesis of G. lemaneiformis in co-culture

22 experiments, through a combination of chemical and nutrient competition. In our study,

23 we attempted to eliminate the effects of nutrient competition by replenishing nutrients 
1 daily. It should be noted, however, that nitrate was used as a proxy for all nutrients in the

2 seawater media and concentrations of other essential nutrients (e.g. phosphorus, trace

3 minerals) were not measured. Despite this, we believe that nutrient limitation was

4 unlikely since the uptake rate of nitrogen is generally several times higher than the uptake

5 of other nutrients in macroalgae (Wallentinus 1984). Additionally, although previous

6 studies have indicated that Ulva and Gracilaria have similar nitrogen uptake rates

7 (Wallentinus 1984, Naldi \& Wheeler 2002), we saw no negative effect on the growth rate

8 of G. vermiculophylla in our control trials, which suggests that nitrogen limitation did not

9 occur. However, we cannot completely eliminate the possibility that nutrient competition

10 played a role in our study. Future studies should test the concentrations of all nutrients to

11 eliminate nutrient competition as a mechanism.

12 We found that nutrient replete $U$. compressa caused significant mortality in oyster

13 larvae, while nutrient deplete Ulva extract had no significant effect on larval mortality.

14 Other studies have shown that bryozoan and hydroid larvae can be negatively impacted

15 by brown algae (Schmitt et al. 1998), red algae can cause necrosis in soft corals (de Nys

16 et al. 1991), and green algae can negatively affect the development of Pacific oyster

17 larvae (Nelson \& Gregg 2013), growth rate of adult Pacific oysters (Nelson et al. 2003,

18 Nelson \& Gregg 2013, Van Alstyne et al. 2014), and metamorphosis of crab larvae (Van

19 Alstyne et al. 2014). Interestingly, several studies have reported that the toxicity of

20 phytoplankton increased under nutrient limitation. For example, the haptophyte

21 Prymesium parvum causes significant mortality in other phytoplankton species and the

22 toxicity of $P$. parvum was enhanced under nutrient limited conditions (Granéli \&

23 Johansson 2003, Uronen et al. 2005, reviewed by Granéli et al. 2008). Ribalet et al. 
1 (2007) reported that production of toxic polyunsaturated aldehydes (PUAs) by marine

2 diatoms increased under nutrient limitation. Our results indicate that $U$. rigida grown

3 under nutrient deplete conditions had a stronger negative effect on oyster larval survival,

4 although this trend was not statistically significant. Contrastingly, Nan et al. (2008)

5 showed that Ulva lactuca caused mortality in microalgae under nutrient replete

6 conditions, similar to our findings for $U$. compressa.

7 Previous researchers have also demonstrated that the effect of macroalgae on co-

8 occurring species is dependent on species-specific characteristics. For example, Accoroni

9 et al. (2015) showed that co-culture with fresh thalli of the brown alga Dictyota

10 dichotoma had a stronger negative effect on the growth of the benthic diatom Ostreopsis

11 cf. ovata than co-culture with $U$. rigida. There are also species-specific effects within the

12 Ulvales. Nelson et al. (2003) showed that extract from U. obscura more strongly

13 inhibited the germination of Fucus gardneri than extract from U. fenestrata.

14 In our laboratory-based mesocosms studies, both $U$. compressa and U. rigida inhibited

15 the growth of G. vermiculophylla and there was no significant difference in the growth of

16 G. vermiculophylla between the Ulva treatments. However, our results from outdoor

17 flow-through seawater tank trials showed that only U. compressa significantly suppressed

18 the growth of G. vermiculophylla. Although there was a trend of reduced $G$.

19 vermiculophylla growth in the U. rigida treatment, there was no significant effect of co-

20 culture with $U$. rigida, likely due to low replication. Furthermore, we documented

21 consistent, contrasting responses of oyster larvae to exudate of $U$. compressa and $U$.

22 rigida. Therefore, we hypothesize that the mechanisms responsible for the negative

23 effects of $U$. compress $a$ and $U$. rigida on co-occurring organisms are species specific. 
The three co-occurring macroalgae tested here also responded differently to $U$.

2 compressa and $U$. rigida. For example, the native $C$. purpureum began to lose mass or

3 show negligible growth in the presence of $U$. compressa and $U$. rigida after 4 and 6 days

4 of co-culture, respectively. Chondrus crispus grown in the presence of both Ulva species

5 had lower growth rates, but only began to lose mass after 8 days of co-culture with $U$.

6 compressa. Interestingly, the non-native G. vermiculophylla appeared to be the least

$7 \quad$ affected of the three macroalgae tested; G. vermiculophylla did not experience a

8 significant reduction in growth rate in either Ulva treatment until 8 days of co-culture had

9 passed and never began to lose mass. Differences in the response of species to ulvoids

10 have also been documented in phytoplankton (Tang \& Gobler 2011) and could have

11 ecological consequences for species presence and abundance in or near macroalgal

12 blooms. In Narragansett Bay, Gracilaria spp. is very common in blooms (Thornber et al.

13 2017), perhaps owing to its ability to coexist with $U$. compressa and $U$. rigida. Species

14 interactions shape ecological communities and the impacts of $U$. compressa and $U$. rigida

15 on community composition require further research.

16 The responses documented here could be the result of allelopathy (i.e. chemical

17 inhibition) by $U$. compressa and $U$. rigida. However, identifying chemically mediated

18 interactions depends on detection of chemicals at or near the alga surface (Steinberg and

19 de Nys 2002). Therefore, this hypothesis cannot be validated until allelochemicals are

20 detected, isolated, and identified from U. compressa and U. rigida, and the effect of those

21 isolated allelochemicals on target species is tested. Furthermore, it is important to note

22 that Ulva can also compete with co-occurring macroalgae through other mechanisms

23 such as nutrient competition (discussed above) or through $\mathrm{pH}$ alteration. For example, 
1 Ulva intestinalis has been shown to raise the $\mathrm{pH}$ of rockpools to a level $(>10)$ where

2 seaweeds cannot utilize external carbonic anhydrase (CA) to covert $\mathrm{HCO}_{3}$ - to $\mathrm{CO}_{2}$ for

3 use in photosynthesis, and therefore become carbon limited (Bjork et al. 2004). Chondrus

4 crispus utilizes $\mathrm{HCO}_{3}$ - only through external $\mathrm{CA}$ and becomes bleached when growing in

5 rockpools dominated by $U$. intestinalis due to high $\mathrm{pH}$ (Bjork et al. 2004). Although $\mathrm{pH}$

6 was only measured in the first Chondrus crispus trial, we did document $\mathrm{pH}$ levels that

7 were potentially high enough to interrupt external CA activity. Alterations in $\mathrm{pH}$,

8 however, cannot explain all of the results documented here. In particular, research has

9 shown that species of Gracilaria and closely related Gracilariopsis use both external CA

10 (sensitive to high $\mathrm{pH}$ ) and a direct $\mathrm{HCO}_{3}$ - transporter (not sensitive to $\mathrm{pH}$ ) simultaneously

11 to take up inorganic carbon (Andría et al. 1999, Pérez-Lloréns et al. 2004), yet we

12 documented a negative effect of $U$. compressa on the relative growth rate of Gracilaria

13 vermiculophylla in closed mesocosms. Additionally, in the oyster larval survival assays,

14 we adjusted the $\mathrm{pH}$ of the Ulva exudate to match control seawater (7.9-8.0) prior to use.

15 If $\mathrm{pH}$ were responsible for the negative effects of Ulva on oyster larvae, we should have

16 seen no difference in the survival between treatments.

17 We have demonstrated for the first time that $U$. compressa has a significant

18 negative effect on the survival of eastern oyster larvae, an important aquaculture crop in

19 the U.S. (USDA 2014), when cultured under eutrophic conditions. Approximately two-

20 thirds of U.S. coastal waterways, including Narragansett Bay, are considered degraded by

21 an excess of nitrogen (N) from anthropogenic influences (Howarth \& Marino 2006).

22 Excess nutrients are known to cause blooms of ulvoid macroalgae (Teichberg et al. 2010)

23 and our results suggest that $U$. compressa can cause mortality in oyster larvae in these 
1 systems especially when oyster spawning coincides with the occurrence of Ulva blooms.

2 Interestingly, $U$. rigida did not cause significant mortality of oyster larvae, although it did

3 inhibit the growth of co-occurring macroalgae. One important caveat of this study is the

4 lack of validation of these effects in situ. While we did use ecologically relevant

5 concentrations of Ulva in our study, these results are likely to change as a result of

6 hydrodynamics (Steinberg et al. 2002). Further research is required to examine the effects

7 of Ulva on other economically important bivalves (e.g. clams and scallops) and on post-

8 larval eastern oysters and to verify these effects in situ.

\section{Acknowledgements}

11 We would like to thank I. Burns, K. Carpentier, L. Dansereau, and C. Anderson

12 for laboratory and/or logistical help. Funding was provided by the Rhode Island Science

13 and Technology Council and the National Science Foundation EPSCoR Cooperative

14 Agreement \#EPS-1004057. This research is based in part upon work conducted using the

15 Rhode Island Genomics and Sequencing Center and the Marine Life Sciences Facility.

16 We are thankful to three anonymous reviewers for their insightful feedback that greatly

17 improved this manuscript.

\section{References}

19 Accoroni S, Percopo I, Cerino F, Romagnoli T, Pichierri, S, Perrone C, Totti C (2015)

20 Allelopathic interactions between the HAB dinoflagellate Ostreopsis cf. ovata and

21 macroalgae. Harmful Algae 49:147-155

22 Angell AR, Pirozzi I, de Nys R, Paul NA (2012) Feeding preferences and the nutritional

23 value of tropical algae for the abalone Haliotis asinina. PLoS ONE 7: e38857. 
1 Anderson DM (2009) Approaches to monitoring, control and management of harmful

2 algal blooms (HABs). Ocean Coast Manage 52:342-347

3 Andría JR, Pérez-Lloréns L, Vergara JJ (1999) Mechanisms of inorganic carbon

4 acquisition in Gracilaria gaditana nom. prov. (Rhodophyta). Planta 208:564-573

5 Atkins RP, Deeley DM, Alpine KW (1993) Managing the aquatic environment. Fert Res

$6 \quad 36: 171-175$

7 Beutel D (2017) Aquaculture in Rhode Island: 2016 Annual Status Report. Coastal

8 Resources Management Council. Wakefield, RI.

9 Bjork M, Axelsson L, Beer S (2004) Why is Ulva intestinalis the only macroalga

10 inhabiting isolated rockpools along the Swedish Atlantic coast? Mar Ecol Prog Ser

$11 \quad 284: 109-116$

12 Borowsky R, Borowsky B (1990) Feeding inhibition of the salt marsh amphipod

13 Gammarus palustris Bousfield, 1969 by heat-labile substances in Ulva lactuca L.

$14 \quad$ Crustaceana 59: 299-301

15 Bricker SB, Longstaff B, Dennison W, Jones A, Boicourt K, Wicks C, Woerner J (2008)

16 Effects of nutrient enrichment in the nation's estuaries: A decade of change. Harmful

$17 \quad$ Algae 8:21-32

18 Connor PM (1972) Acute toxicity of heavy metals to some marine larvae. Mar Pollut

19 Bull 3(12):190-192.

20 Cummins SP, Roberts DE, Zimmerman KD (2004) Effects of the green macroalga

21 Enteromorpha intestinalis on macrobenthic and seagrass assemblages in a shallow

22 coastal estuary. Mar Ecol Prog Ser 266:77-87

23 de Nys R, Coll JC, Price IR (1991) Chemically mediated interactions between the red 
1 alga Plocamium hamatum (Rhodophyta) and the octocoral Sinularia cruciata

2 (Alcyonacea). Mar Biol 108:315-320

3 Deacutis CF, Murray D, Prell W, Saarman E (2006) Hypoxia in the upper half of

$4 \quad$ Narragansett Bay, RI, during August 2001 and 2002. Northeast Nat 13:173-198

5 Doyle JJ, Doyle JL (1987) A rapid DNA isolation procedure for small quantities of fresh

6 leaf tissue. Phytochem Bull 19:11-15

7 Epifanio CE, Srna RF (1975) Toxicity of ammonia, nitrite ion, nitrate ion, and

8 orthophosphate to Mercenaria mercenaria and Crassostrea virginica. Mar Biol

$9 \quad 33: 241-246$

10 Fletcher RL (1996) The British Isles. In: Schramm W, Nienhuis PH, editors. Marine

11 benthic vegetation: recent changes, the effects of eutrophication. Berlin: Springer. pp.

$12 \quad 7-223$

13 Gao, Z, Xu D, Meng C, Zhang X, Wang Y, Li D, Zou J (2014) The green tide-forming

14 macroalga Ulva linza outcompetes the red macroalga Gracilaria lemaneiformis via

15 allelopathy and fast nutrients uptake. Aquat Ecol 48:53-62

16 Granéli E, Johansson N (2003) Increase in the production of allelopathic substances by

17 Prymnesium parvum cells grown under N- or P-deficient conditions. Harmful Algae

$18 \quad 2: 135-145$

19 Granéli E, Weberg M, Salomon PS (2008) Harmful algal blooms of allelopathic

20 microalgal species: The role of eutrophication. Harmful Algae 8:94-102

21 Granger S, Brush MJ, Buckley BA, Schwartz ML (2000) An assessment of

22 eutrophication in Greenwich Bay. In: Schwartz M (ed) Restoring Water Quality in

23 Greenwich Bay A Whitepaper Series. Narragansett, R.I. 
1 Green-Gavrielidis L, Ernst E, Valentin Guttandin J, Thornber C (2017) Monitoring

2 seaweed abundance and species composition at Napatree lagoon. In: Stassi J, editor,

3 The State of Napatree Report: 2017, 191 pp.

4 Guidone M, Thornber CS (2013) Examination of Ulva bloom species richness and

5 relative abundance reveals two cryptically co-occurring bloom species in

6 Narragansett Bay, Rhode Island. Harmful Algae 24:1-9

7 Guidone M, Thornber C, Wysor B, O'Kelly CJ (2013) Molecular and morphological

8 diversity of Narragansett Bay (RI, USA) Ulva (Ulvales, Chlorophyta) populations. J

9 Phycol 49:979-995

10 Harlin MM (1987) Allelochemistry in marine macroalgae. Crit Rev Plant Sci 5:237-249.

11 His E, Beiras R, Searman MNL (1999) The assessment of marine pollution: bioassays

12 with bivalve embryos and larvae. In: AI Southward, PA Tyler, and CM Young (Eds)

13 Advances in Marine Biology, Vol. 37. London: Academic Press

14 Hofmann LC, Nettleton JC, Neefus CD, Mathieson AC (2010) Cryptic diversity of Ulva

15 (Ulvales, Chlorophyta) in the Great Bay Estuarine System (Atlantic USA):

16 introduced and indigenous distromatic species. Eur J Phycol 45:230-239

17 Howarth RW, Marino R (2006) Nitrogen as the limiting nutrient for eutrophication in

18 coastal marine ecosystems: Evolving views over three decades. Limnol Oceanogr

$19 \quad 51: 364-376$

20 Huggett MJ, de Nys R, Williamson JE, Heasman M, Steinberg PD (2005) Settlement of

21 larval blacklip abalone, Haliotis rubra, in response to green and red macroalgae. Mar

$22 \quad$ Biol 147:1155-1163

23 Hurd CL, Harrison PJ, Bischof K, Lobban CS (2014) Seaweed ecology and physiology: 
1 second edition. Cambridge University Press, $551 \mathrm{pp}$.

2 Jin Q, Dong S (2003) Comparative studies on the allelopathic effects of two different

3 strains of Ulva pertusa on Heterosigma akashiwo and Alexandrium tamarense. J Exp

$4 \quad$ Mar Biol Ecol 293:41-55

5 Johnson DA, Welsh BL (1985) Detrimental effect of Ulva lactuca (L.) exudates and low

6 oxygen on estuarine crab larvae. J Exp Mar Biol Ecol 86:73-83

7 Karim M, Zhao W, Rowley D, Nelson D, Gomez-Chiarri M (2013) Probiotic strains for

8 shellfish aquaculture: protection of Eastern oyster, Crassostrea virginica, larvae and

9 juveniles against bacterial challenge. J Shellfish Res 32:401-408

10 Lamb A (2015) Understanding the impact of sea lettuce (Ulva spp.) density on Pacific

11 oyster (Crassostrea gigas) growth in Puget Sound, Washington. Master's Thesis, The

12 Evergreen State College

13 Lapointe BE, Bedford BJ (2007) Drift rhodophyte blooms emerge in Lee County,

14 Florida, USA: Evidence of escalating coastal eutrophication. Harmful Algae 6:421-

$15 \quad 437$

16 Liu D, Keesing JK, He P, Wang Z, Shi Y, Wang Y (2013) The world's largest macroalgal

17 bloom in the Yellow Sea, China: Formation and implications. Estuar Coast Shelf S

$18 \quad 129: 2-10$

19 Magre EJ (1974) Ulva lactuca L. negatively affects Balanus balanoides (L.)(Cirripedia

20 Thoracica) in tidepools. Crustaceana 27:231-234

21 McGlathery KJ (2001) Macroalgal blooms contribute to the decline of seagrass in

22 nutrient-enriched coastal waters. J Phycol 37:453-456

23 Muñoz P, Ambler R, Bulboa C (2012) Settlement, survival, and post-larval growth of red 
1 abalone, Haliotis rufescens, on polycarbonate plates treated with germlings of Ulva

2 sp. J World Aquacult Soc 43:890-895

3 Naldi M, Wheeler PA (2002) ${ }^{15} \mathrm{~N}$ measurements of ammonium and nitrate uptake by

$4 \quad$ Ulva fenestrata (Chlorophyta) and Gracilaria pacifica (Rhodophyta): comparison of

5 net nutrient disappearance, release of ammonium and nitrate, and ${ }^{15} \mathrm{~N}$ accumulation

6 in algal tissue. J Phycol 38:135-144

7 Nan C, Zhang H, Lin S, Zhao G, Liu X (2008) Allelopathic effects of Ulva lactuca on

8 selected species of harmful bloom-forming microalgae in laboratory cultures. Aquat

$9 \quad$ Bot $89: 9-15$

10 Nelson TA, Gregg BC (2013) Determination of EC50 for normal oyster larval

11 development in extracts from bloom-forming green seaweeds. Nautilus 127:156-159

12 Nelson TA, Lee DJ, Smith BC (2003) Are "green tides" harmful algal blooms? Toxic

13 properties of water-soluble extracts from two bloom-forming macroalgae, Ulva

14 fenestrata and Ulvaria obscura (Ulvophyceae). J Phycol 39:874-879

15 Nettleton JC (2012) Tracking environmental trends in the Great Bay Estuarine System:

16 An examination of water quality and nuisance macroalgal blooms. Dissertation,

17 University of New Hampshire

18 Nettleton JC, Mathieson AC, Thornber C, Neefus CD, Yarish C (2013) Introduction of

19 Gracilaria vermiculophylla (Rhodophyta, Gracilariales) to New England, USA:

20 Estimated arrival times and current distribution. Rhodora 115(961): 28-41

21 Ott FD (1966) A selected listing of xenic cultures. Systematics-Ecology Program No. 72

22 (Mar. Biol. Lab., Woods Hole, MA), pp 1-45

23 Peckol P, Putnam AB (2017) Differential toxic effects of Ulva lactuca (Chlorophyta) on 
1 the herbivorous gastropods, Littorina littorea and L. obtusata (Mollusca) J Phycol

$2 \quad 53: 361-367$

3 Pérez-Lloréns JL, Brun FG, Andría J, Vergara JJ (2004) Seasonal and tidal variability of

4 environmental carbon related physico-chemical variables and inorganic $\mathrm{C}$ acquisition

5 in Gracilariopsis longissima and Enteromorpha intestinalis from Los Toruños salt

6 marsh (Cádiz Bay, Spain). J Exp Mar Biol Ecol 304:183-201

7 Rafaelli D, Raven JA, Poole LJ (1998) Ecological impact of mass blooms of

8 benthic algae. Mar Biol Oceanogr Ann Rev 36: 97-125

9 Ribalet F, Wichard T, Pohnert G, Ianora A, Miralto A, Casotti R (2007) Age and nutrient

10 limitation enhance polysaturated aldehyde production in marine diatoms.

11 Phytochemistry 68:2059-2067

12 Schmitt TM, Lindquist N, Hay ME (1998) Seaweed secondary metabolites as

13 antifoulants: effects of Dictyota spp. diterpenes on survivorship, settlement, and

14 development of marine invertebrate larvae. Chemoecology 8:125-131

15 Shimada S, Hiraoka M, Nabata S, Iima M, Masuda M (2003) Molecular phylogenetic

16 analyses of the Japanese Ulva and Enteromorpha (Ulvales, Ulvophyceae), with

17 special reference to the free-floating Ulva. Phycol Res 51:99-108

18 Smetacek V, Zingone A (2013) Green and golden seaweed tides on the rise. Nature $19 \quad 504: 84-88$

20 Sohn S, Lundgren KM, Tammi K, Karim M, Smolowitz R, Nelson DR, Rowley DC,

21 Gómez-Chiarri M (2016) Probiotic strains for disease management in hatchery

22 larviculture of the Eastern oyster Crassostrea virginina. J Shellfish Res 35:307-317

23 Steinberg PD, de Nys R (2002) Chemical mediation of colonization of seaweed surfaces. 
$1 \quad$ J Phycol 38:621-629

2 Steinberg PD, de Nys R, Kjelleberg S (2002) Chemical cues for surface colonization. J

$3 \quad$ Chem Ecol 28:1935-1951

4 Tang YZ, Gobler CJ (2011) The green macroalga, Ulva lactuca, inhibits the growth of

5 seven common harmful algal bloom species via allelopathy. Harmful Algae 10: 480-

$6 \quad 488$

7 Teichberg M, Fox S, Olsen Y, Valiela I, Martinetto P, Iribarne O, Muto EY, Petti M,

8 Corbisier T, Soto-Jimenez M, Paez-Osuna F, Castro P, Freitas H, Zitelli A,

9 Cardinaletti M, Tagliapietra D (2010) Eutrophication and macroalgal blooms in

10 temperate and tropical coastal waters: nutrient enrichment experiments with Ulva

11 spp. Glob Change Biol 16:2624-2637

12 Thornber CS, Dimilla P, Nixon SW, McKinney RA (2008) Natural and anthropogenic

13 nitrogen uptake by bloom-forming macroalgae. Mar Pollut Bull 56:261-269

14 Thornber CS, Guidone M, Deaucutis C, Green L, Ramsay CN, Palmisciano M (2017)

15 Spatial and temporal variability in macroalgal blooms in a eutrophied coastal

16 estuary. Harmful Algae 68:82-96.

17 Thorne-Miller B, Harlin M, Thursby G, Brady-Campbell M, Dworetzky B (1983)

18 Variations in the distribution and biomass of submerged macrophytes in five coastal

19 lagoons in Rhode Island, U.S.A. Botanica Marina 26, 231-242

20 Tyler AC, McGlathery KJ, Anderson IC (2001) Macroalgae mediation of dissolved

21 organic nitrogen fluxes in a temperate coastal lagoon. Estuar Coast Shelf S 53:155-

$22 \quad 168$

23 Underwood AJ (1997) Experiments in ecology: their logical design and interpretation 
1 using analysis of variance. Cambridge University Press. 508 pp.

2 Uronen P, Lehtinen S, Legrand C, Kuuppo P, Tamminen T (2005) Haemolytic activity

3 and allelopathy of the haptophyte Prymnesium parvum in nutrient-limited and

4 balanced growth conditions. Mar. Ecol. Prog. Ser. 299:137-148.

$5 \quad$ USDA (United States Department of Agriculture) (2014) Census of Aquaculture 2013.

6 Valiela I, Cole ML (2002) Comparative evidence that salt marshes and mangroves may

7 protect seagrass meadows from land-derived nitrogen loads. Ecosystems 5:92-102

8 Valiela I, McClelland J, Hauxwell J, Behr PJ, Herh D, Foreman K (1997) Macroalgal

9 blooms in shallow estuaries: Controls and ecophysiological and ecosystem

10 consequences. Limnol Oceanogr 42:1105-1118.

11 Van Alstyne KL, Harvey EL, Cataldo M (2014) Effects of dopamine, a compound

12 released by the green-tide macroalga Ulvaria obscura (Chlorophyta), on marine

13 algae and invertebrate larvae and juveniles. Phycologia 53:195-202

14 Van Alstyne KL, Nelson TA, Ridgway RL (2015) Environmental chemistry and

15 chemical ecology of "green tide" seaweed blooms. Integr Comp Biol 55:518-532

16 Wallentinus I (1984) Comparisons of nutrient uptake rates for Baltic macroalgae with

17 different thallus morphologies. Mar Biol 80:215-225

18 Walters LJ, Hadfield MG, Smith CM (1996) Waterborne chemical compounds in tropical

19 macroalgae: positive and negative cues for larval settlement. Mar Biol 126:383-393.

20 Wang R, Feng W, Tang X, Wang J, Dong S (2012) Allelopathic growth inhibition of

21 Heterosigma akashiwo by the three Ulva species (Ulva pertusa, Ulva linza,

22 Enteromorpha intestinalis) under laboratory conditions. Acta Oceanol Sin 31:138-

$23 \quad 144$


1 Worm B, Lotze HK (2006) Effects of eutrophication, grazing, and algal blooms on rocky

$2 \quad$ shores. Limnol Oceanogr 51:569-579 


\section{Figure Legend}

2 Figure 1. Mean relative growth rate $\left(\% \mathrm{~d}^{-1}\right)$ of a) Gracilaria vermiculophylla b)

3 Cystoclonium purpureum and c) Chondrus crispus co-cultured with U. compressa, $U$.

4 rigida, or alone (control). Error bars represent \pm 1 SE. Asterisks $(*)$ denote a statistically

5 significant difference based on Tukey's HSD post hoc comparisons. The results of

6 posthoc comparisons for $C$. purpureum and C. crispus are available in Table 2 and 3,

7 respectively.

8 Figure 2. Relative percent survival of oyster larvae exposed to exudate from $U$.

9 compressa and $U$. rigida grown under nutrient replete (+ Nutrients) or nutrient deplete (-

10 Nutrients) conditions. Bars with a letter in common are not statistically different based on

11 Tukey’s HSD post hoc comparisons. Error bars represent $\pm 1 \mathrm{SE}$.

12 

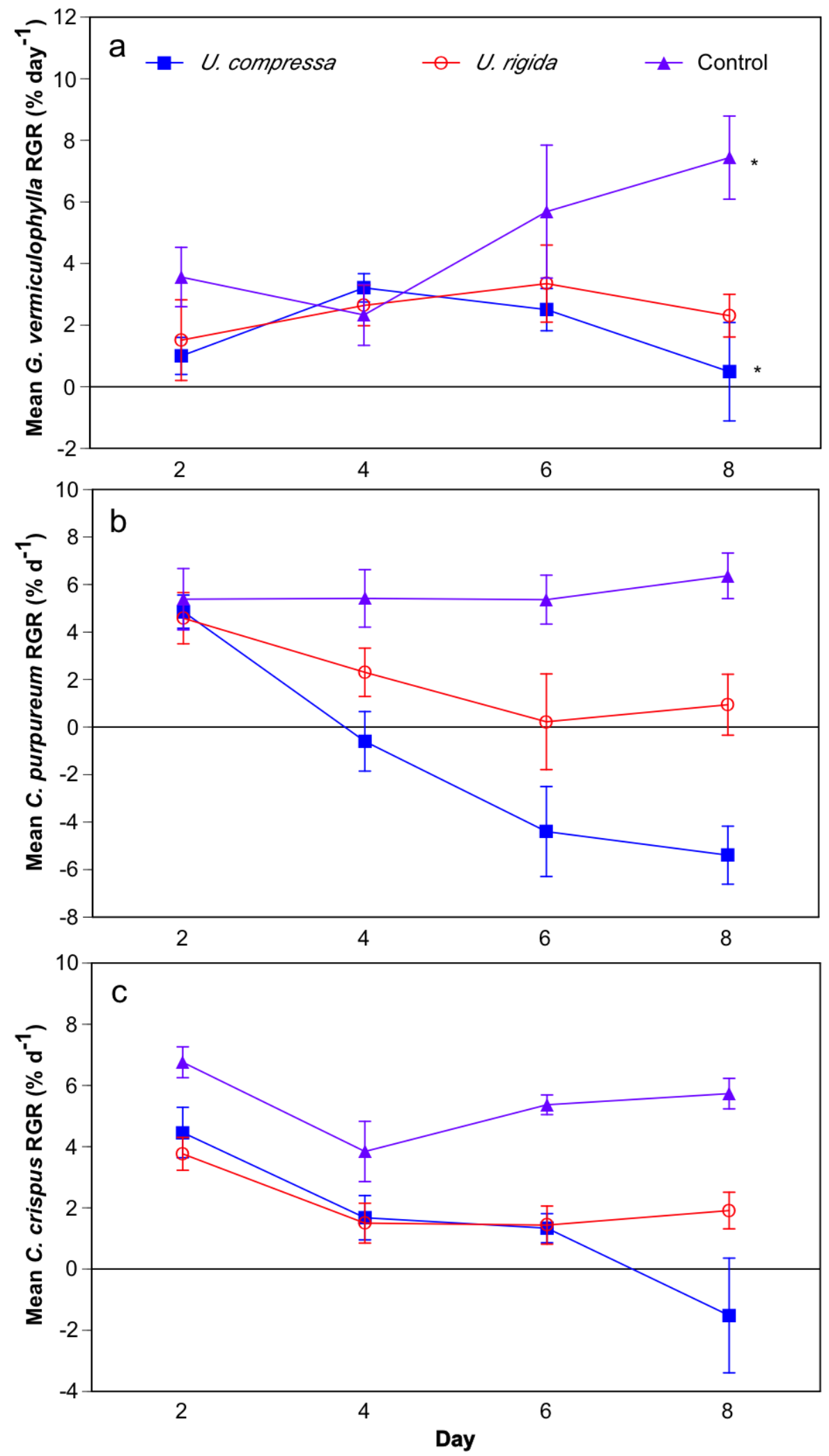

1 Figure 1. 


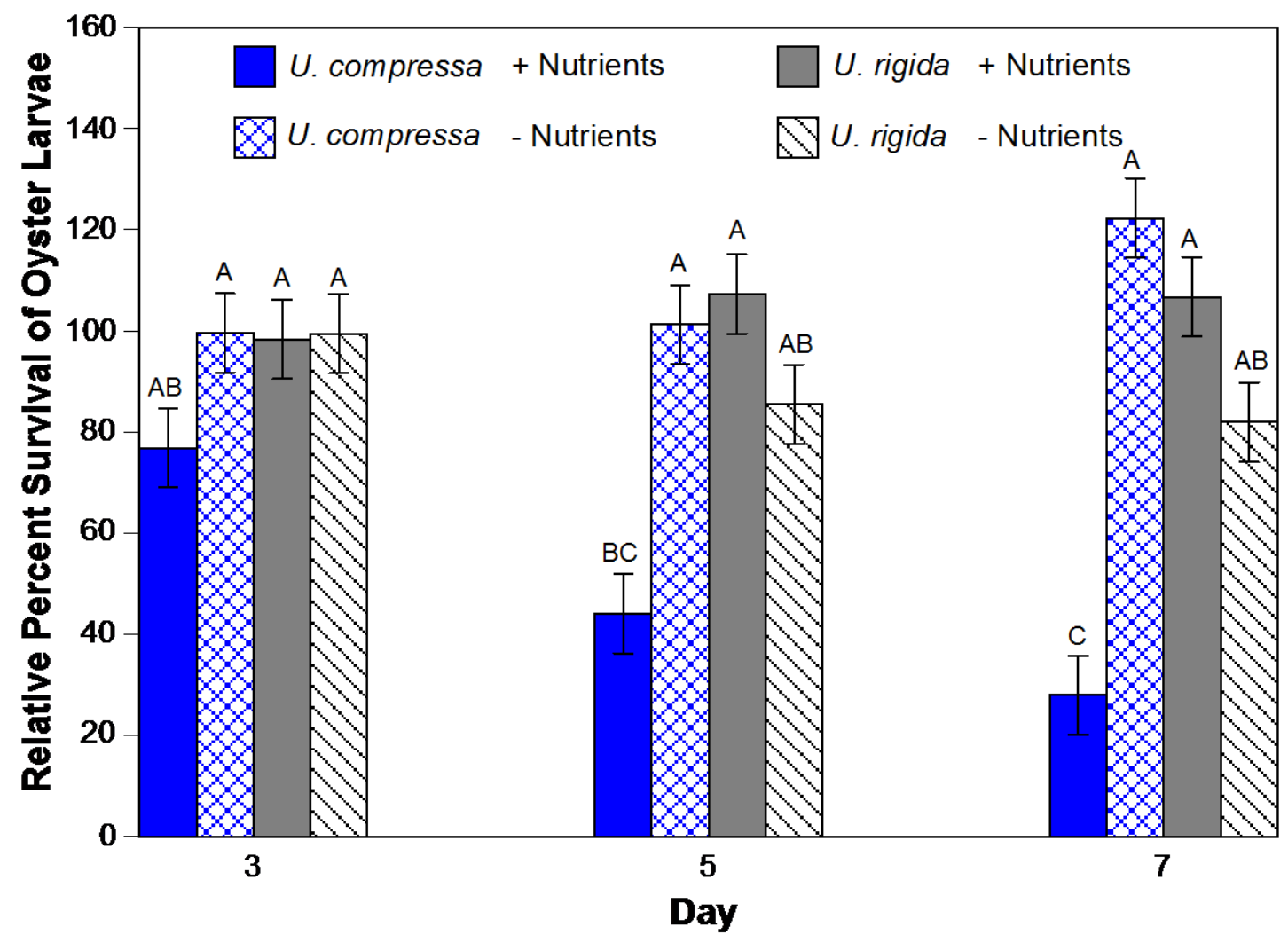

2 Figure 2.

3

4 
1 Table 1: Selected examples of studies documenting the effects of ulvoid macroalgae

2 (Family Ulvophyceae) on co-occurring organisms.

3

\begin{tabular}{|l|l|l|l|}
\hline \multicolumn{1}{|c|}{ Location } & Macroalgal Taxa & \multicolumn{1}{|c|}{ Documented Effects } & \multicolumn{1}{c|}{ Reference(s) } \\
\hline Washington, U.S.A & U. obscura & $\begin{array}{l}\text { Inhibited development of } \\
\text { Fucus zygotes and crab } \\
\text { larvae, growth of Ulva lactuca }\end{array}$ & $\begin{array}{l}\text { Van Alstyne et al. } \\
2014\end{array}$ \\
\hline Washington, U.S.A & $\begin{array}{l}\text { U. lactuca, } \text { U. } \\
\text { obscura, and/or } U . \\
\text { fenestrata }\end{array}$ & $\begin{array}{l}\text { Inhibited development of } \\
\text { Fucus zygotes, growth of } \\
\text { Ulva, Ulvaria, and epiphytic } \\
\text { macroalgae, inhibited/killed } \\
\text { oyster larvae }\end{array}$ & $\begin{array}{l}\text { Nelson et al. 2003, } \\
\text { Nelson \& Gregg } \\
2013\end{array}$ \\
\hline Hawaii, U.S.A. & U. reticulata & $\begin{array}{l}\text { Inhibited/killed fouling } \\
\text { invertebrates }\end{array}$ & Walters et al. 1996 \\
\hline New York, U.S.A. & U. lactuca & $\begin{array}{l}\text { Inhibited feeding of } \\
\text { amphipod; inhibited growth of } \\
\text { multiple harmful microalgal } \\
\text { species }\end{array}$ & $\begin{array}{l}\text { Borowsky \& } \\
\text { Borowsky 1990, } \\
\text { Tang \& Gobler 2011 }\end{array}$ \\
\hline Connecticut, U.S.A. & U. lactuca & $\begin{array}{l}\text { Killed barnacles; killed zoeae } \\
\text { crab larvae }\end{array}$ & $\begin{array}{l}\text { Magre 1974, Johnson } \\
\text { \& Welsh 1985 }\end{array}$ \\
\hline Sirolo, Italy & U. rigida & $\begin{array}{l}\text { Inhibited growth of toxic } \\
\text { benthic dinoflagellate }\end{array}$ & Accoroni et al. 2015 \\
\hline Qingdao, China & $\begin{array}{l}\text { U. pertusa, } U . \\
\text { linza, } \text { U. } \\
\text { intestinalis, and/or } \\
\text { U. lactuca }\end{array}$ & $\begin{array}{l}\text { Inhibited growth of red tide } \\
\text { microalgae }\end{array}$ & $\begin{array}{l}\text { Jin \& Dong 2003, } \\
\text { Nan et al. 2008, } \\
\text { Wang et al. 2012 }\end{array}$ \\
\hline
\end{tabular}

4 
1 Table 2. Mean relative growth rate (RGR; \% $\mathrm{d}^{-1}$ ) of Cystoclonium purpureum tips

2 cultured with $U$. compressa, $U$. rigida, or alone (mesocosm control). Means without a

3 common superscript letter differ significantly $(\mathrm{p}<0.05)$ based on Tukey's HSD post hoc

4 comparisons.

5

\begin{tabular}{|c|c|c|}
\hline Days of Co-culture & Treatment & RGR $\left(\% \mathbf{~ d}^{\mathbf{1}}\right) \pm \mathbf{1 S E}$ \\
\hline \multirow{4}{*}{2} & U. compress $a$ & $4.89 \pm 0.70^{\mathrm{abc}}$ \\
\cline { 2 - 3 } & U. rigida & $4.58 \pm 1.08^{\mathrm{abc}}$ \\
\cline { 2 - 3 } & Mesocosm control & $5.38 \pm 1.29^{\mathrm{ab}}$ \\
\hline \multirow{4}{*}{4} & U. compressa & $-0.60 \pm 1.25^{\mathrm{cde}}$ \\
\cline { 2 - 3 } & U. rigida & $2.31 \pm 1.02^{\mathrm{abc}}$ \\
\cline { 2 - 3 } & Mesocosm control & $5.42 \pm 1.21^{\mathrm{ab}}$ \\
\hline \multirow{5}{*}{6} & U. compressa & $-4.40 \pm 1.89^{\mathrm{de}}$ \\
\cline { 2 - 3 } & U. rigida & $0.22 \pm 2.01^{\mathrm{bcde}}$ \\
\cline { 2 - 3 } & Mesocosm control & $5.36 \pm 1.03^{\mathrm{ab}}$ \\
\hline \multirow{5}{*}{8} & U. compressa & $-5.39 \pm 1.22^{\mathrm{e}}$ \\
\cline { 2 - 3 } & U. rigida & $0.94 \pm 1.28^{\mathrm{abcd}}$ \\
\cline { 2 - 3 } & Mesocosm control & $6.37 \pm 0.96^{\mathrm{a}}$ \\
\hline
\end{tabular}

6

7

8

10

11

\begin{tabular}{|c|c|c|}
\hline Days of Co-culture & Treatment & RGR $\left(\mathbf{m g ~ d}^{\mathbf{1}}\right) \mathbf{\pm 1 S E}$ \\
\hline \multirow{4}{*}{2} & U. compressa & $4.46 \pm 0.82^{\mathrm{abc}}$ \\
\cline { 2 - 3 } & U. rigida & $3.76 \pm 0.54^{\mathrm{abc}}$ \\
\cline { 2 - 3 } & Mesocosm control & $6.76 \pm 0.50^{\mathrm{a}}$ \\
\hline \multirow{4}{*}{4} & U. compressa & $1.68 \pm 0.72^{\mathrm{cd}}$ \\
\cline { 2 - 3 } & U. rigida & $1.50 \pm 0.65^{\mathrm{cd}}$ \\
\cline { 2 - 3 } & Mesocosm control & $3.84 \pm 0.98^{\mathrm{abc}}$ \\
\hline \multirow{4}{*}{6} & U. compressa & $1.34 \pm 0.47^{\mathrm{cd}}$ \\
\cline { 2 - 3 } & U. rigida & $1.44 \pm 0.62^{\mathrm{cd}}$ \\
\cline { 2 - 3 } & Mesocosm control & $5.37 \pm 0.32^{\mathrm{ab}}$ \\
\hline \multirow{4}{*}{8} & U. compressa & $-1.52 \pm 1.87^{\mathrm{d}}$ \\
\cline { 2 - 3 } & U. rigida & $1.91 \pm 0.60^{\mathrm{bcd}}$ \\
\cline { 2 - 3 } & Mesocosm control & $5.73 \pm 0.50^{\mathrm{a}}$ \\
\hline
\end{tabular}

Table 3. Mean relative growth rate (RGR; \% day ${ }^{-1}$ ) of Chondrus crispus tips cultured with $U$. compressa, $U$. rigida, or alone (mesocosm control). Means without a common superscript letter differ significantly $(\mathrm{p}<0.05)$ based on Tukey's HSD post hoc comparisons.

12 